\title{
Analisis Kesulitan Belajar Matematika dalam Menyelesaikan Soal Cerita
}

\author{
*Dian Rizky Utari1 ${ }^{1}$, M. Yusuf Setia Wardana², Aries Tika Damayani ${ }^{3}$
}

${ }^{123} J u r u s a n$ Pendidikan Guru Sekolah Dasar, Fakultas Ilmu Pendidikan, Universitas PGRI Semarang, Indonesia

\author{
A R T I C L E I N F O \\ Article history: \\ Received 15 August 2019 \\ Received in revised form \\ 20 September 2019 \\ Accepted 10 October 2019 \\ Available online 30 \\ November 2019 \\ Kata Kunci: \\ kesulitan belajar, soal cerita \\ Keywords: \\ difficulties in studying, story \\ problems
}

\begin{abstract}
A B S T R A K
Siswa berkesulitan belajar matematika sering melakukan kekeliruan dalam belajar berhitung dan kekeliruan dalam menyelesaikan soal cerita. Kesulitan yang sering dialami oleh siswa yaitu kesulitan saat mengerjakan soal cerita karena kurang mampu memahami maksud soal dan kebingungan saat menentukan operasi hitung yang akan dipakai. Tujuan dari penelitian ini adalah untuk mengetahui jenis kesulitan belajar matematika yang dialami siswa, faktor yang mempengaruhi kesulitan belajar, dan mengungkapkan upaya yang dapat dilakukan untuk mengatasi kesulitan belajar matematika di kelas IV Sekolah Dasar. Metode penelitian ini menggunakan deskriptif kualitatif. Subyek penelitian yaitu siswa kelas IV sebanyak 10 orang dan guru kelas IV. Prosedur pengumpulan data yang digunakan adalah observasi, wawancara, teknik tes dan dokumentasi. Hasil Penelitian menunjukkan bahwa siswa kelas IV yang berjumlah 10 siswa dari 15 siswa mengalami kesulitan belajar matematika dalam menyelesaikan soal
\end{abstract} cerita. Kesulitan belajar matematika menyelesaikan soal cerita yang terjadi di kelas IV SD meliputi kesulitan memahami konsep, kesulitan dalam keterampilan, dan kesulitan memecahkan masalah. Faktor yang menyebabkan kesulitan belajar matematika berasal dari faktor internal dan faktor eksternal. Faktor internal yang berasal dari siswa meliputi IQ atau intelegensi, sikap siswa dalam belajar matematika, motivasi belajar siswa yang masih rendah, kesehatan tubuh yang tidak optimal, dan kemampuan pengindraan siswa yang kurang. Sedangkan faktor eksternal yang berasal dari luar siswa antara lain kurangnya variasi mengajar guru, penggunaan media pembelajaran yang belum maksimal, sarana prasarana di sekolah, serta lingkungan keluarga.

\begin{abstract}
A B S T R A C T
Students having difficulty learning mathematics often make mistakes in learning to count and mistakes in solving story problems. Difficulties that are often experienced by students are difficulties when working on story problems because they are not able to understand the purpose of the questions and confusion when determining the arithmetic operations that will be used. Descriptive qualitative research methods. Sources of research data are students in class IV and teacher in class IV. Data collection procedures used are observation, interviews, test techniques and documentation. The results of the study showed that 10th grade students totaling 10 students out of 15 students had difficulty learning mathematics in solving story problems. Difficulty in learning mathematics to solve story problems that occur in class IV SD Negeri Tambakrejo 03 includes difficulty understanding concepts, difficulties in skills, and difficulty solving problems.
\end{abstract}

\section{Pendahuluan}

Manusia membutuhkan pendidikan dalam kehidupannya, pendidikan merupakan usaha agar manusia dapat mengembangkan potensi yang ada dalam dirinya melalui proses pembelajaran atau cara lain yang sudah dikenal dan diakui oleh masyarakat. Salah satu bentuk dari pendidikan dasar adalah sekolah dasar. Salah satu mata pelajaran di sekolah dasar adalah mata pelajaran matematika. Matematika mempunyai peranan penting dalam berbagai displin ilmu dan memajukan daya pikir manusia seperti yang tercantum dalam (Departemen Pendidikan Nasional, 2006) yaitu peningkatan mutu pendidikan

Copyright (C) Universitas Pendidikan Ganesha. All rights reserved. 
diarahkan untuk meningkatkan kualitas manusia Indonesia seutuhnya melalui olah hati, olah pikir, olah rasa, dan olahraga agar memiliki daya saing dalam menghadapi tantangan global. Matematika diberikan untuk membekali peserta didik dengan kemampuan berpikir logis, analitis, sistematis, kritis dan kreatif, serta kemampuan bekerja sama.

Pembelajaran matematika yang masih rendah disebabkan karena berbagai permasalahan. Salah satu permasalahan dalam pembelajaran matematika yaitu anggapan dari sebagian besar siswa bahwa matematika adalah pelajaran yang sulit dan membosankan, sehingga banyak siswa yang kurang menyukai pelajaran matematika bahkan menjadikan matematika sebagai salah satu pelajaran yang harus dihindari. Padahal siswa yang kurang menyukai pelajaran matematika dapat mengalami kesulitan dalam memahami materi yang disampaikan dan berdampak pada rendahnya prestasi belajar matematika. Hal tersebut sesuai dengan pendapat (Slameto, 2010) bahwa siswa dengan tingkat kecemasan yang tinggi tidak berprestasi sebaik siswa dengan tingkat kecemasan yang rendah.

Pembelajaran matematika di dalam bangku sekolah dasar tidak pernah terlepas dari materi operasi hitung, baik operasi penjumlahan, pengurangan, perkalian maupun pembagian, semua itu salah satunya terkait dengan materi bilangan. Operasi hitung pada bilangan cacah, bilangan bulat, maupun pecahan telah diajarkan di sekolah dasar. Hal ini dikarenakan bahwa operasi hitung pada bilangan cacah, bilangan bulat, maupun pecahan sangat berperan dalam berbagai hitungan matematika. Pembelajaran pecahan sebagai dasar dalam belajar operasi hitung juga dilakukan di kelas IV, yakni mencakup materi menyederhanakan berbagai bentuk pecahan, operasi penjumlahan, serta pengurangan pecahan dan pemecahan masalah matematika.

Pemecahan masalah matematika adalah suatu proses dimana sesorang dihadapkan pada konsep, keterampilan, dan proses matematika untuk memecahkan masalah matematika (Roebyanto, 2017). Pemecahan masalah matematika di sekolah biasanya diwujudkan dalam bentuk soal cerita. Keterampilan siswa dalam menyelesaikan soal cerita terutama yang berkaitan dengan aspek pemecahan masalah sangat berguna dalam kehidupan sehari-hari. Namun, tidak semua siswa dapat dengan mudah mengerjakan soal cerita.

Siswa yang mengalami kesulitan belajar matematika mempunyai beberapa karakteristik. Siswa berkesulitan belajar sering melakukan kekeliruan dalam belajar berhitung, kekeliruan dalam belajar geometri, dan kekeliruan dalam menyelesaikan soal cerita (Runtukahu dan Kandou, (Syafiudin et al., 2014). Karakteristik dan permasalahan kesulitan belajar matematika di atas ditemukan oleh peneliti di SDN Tambakrejo 03 Semarang.

Berdasarkan data nilai semeseter 1 dan hasil wawancara dengan Ibu Irta Rahayu selaku wali kelas IV SD Negeri Tambakrejo 03 Semarang, terlihat bahwa nilai rata-rata matematika siswa rendah, yakni 68. Guru menjelaskan kepada peneliti dari semua mata pelajaran di kelas IV mata pelajaran matematika merupakan mata pelajaran yang tingkat ketercapaian KKMnya rendah terlihat dari hasil nilai semester 1 siswa. Kesulitan yang sering dialami oleh siswa yaitu kesulitan saat mengerjakan soal cerita karena kurang mampu memahami maksud soal dan kebingungan saat menentukan operasi hitung yang akan dipakai. Biasanya siswa membutuhkan waktu yang sangat lama dalam menyelesaikan soal berbentuk cerita. Siswa sering melakukan kesalahan saat menghitung dan siswa kurang teliti dalam mengerjakan soal cerita matematika. Permasalahan tentang rendahnya hasil belajar matematika siswa dan kesulitan siswa dalam menyelesaikan soal cerita matematika mengindikasikan adanya kesalahan dalam proses belajar mengajar sehingga diperlukan adanya perbaikan. Permasalahan pembelajaran matematika tersebut didukung penelitian yang dilakukan oleh (Darjiani et al., 2015) tentang Analisis KesulitanKesulitan Belajar Matematika Siswa Kelas V dalam Implementasi Kurikulum 2013 di SD Piloting SeKabupaten Gianyar Tahun Pelajaran 2014/2015 menunjukkan bahwa siswa mengalami kesulitan pada keterampilan berhitung, kesulitan dalam aspek konsep, dan kesulitan dalam aspek pemecahan masalah. Faktor-faktor yang menyebabkan kesulitan belajar tersebut secara umum meliputi minat dan motivasi, faktor guru, faktor lingkungan sosial dan faktor kurikulum.

Penelitian mengenai analisis kesulitan belajar matematika dalam menyelesaikan soal cerita sebelumnya pernah dilakukan oleh (Nugroho, 2017) dengan judul "Analisis Kesulitan Siswa dalam Menyelesaikan Soal Cerita pada Materi Pecahan Ditinjau dari Pemecahan Masalah Polya". Penelitian tersebut menjelaskan bahwa kesalahan siswa menyelesaikan soal cerita pada materi pecahan dilihat dari aspek-aspek pemecahan masalah, (1) Aspek memahami masalah, yaitu siswa mengalami kesalahan dalam memaknai bahasa soal cerita dan kesalahan membuat model matematikanya. Penyebabnya adalah reasoning (penalaran) siswa yang tidak lengkap atau salah dan kemampuan matematika siswa yang rendah, (2) Aspek merencanakan pemecahan masalah yaitu siswa mempunyai kesalahan dalam menghubungkan antara data untuk mencari data yang dicari dan kesalahan dalam menghubungkan antara konsep satu dengan konsep yang lain. Penyebab kesalahan pada aspek ini adalah pemikiran humanistik siswa, dan (3) Aspek melakasanakan rencana pemecahan masalah, yaitu kesalahan dalam 
mengimplementasikan rumus yang tidak tepat dan penggunaan angka ataupun satuan yang tidak tepat dalam model matematika. Kesalahan pada aspek ini disebabkan oleh reasoning (penalaran) tidak lengkap atau salah dan pemikiran humanistik siswa.

Pernyataan tersebut didukung oleh penelitian yang dilakukan oleh (Rifaldiyah, 2019) tentang penerapan model Problem Based Learning terhadap hasil belajar kognitif pemecahan masalah matematika yang menunjukkan bahwa tingkat pemahaman siswa dalam mata pelajaran matematika masih kurang khususnya pada soal cerita siswa belum benar-benar memahami tentang bagaimana cara memecahkan masalah yang ada dalam soal cerita tersebut, biasanya siswa untuk memahami soal cerita harus membaca berulang-ulang untuk memahami soal. Guru juga masih menggunakan proses pembelajaran konvensional dalam mengajar dan guru belum menemukan model maupun strategi pembelajaran yang cocok untuk menerapkan kepada siswa mengenai materi pemecahan masalah matematika tersebut. Setelah diterapkan model pembelajaran Problem Based Learning (PBL) dapat meningkatkan hasil belajar siswa. Penggunaan model Problem Based Learning efektif terhadap hasil belajar siswa pada materi pemecahan masalah matematika kelas III SD Negeri Kalicari 01 Semarang. Dengan hasil uji hipotesis menggunakan uji T diperoleh $t_{\text {hitung }} 2,680$ sementara $\mathrm{dk}=23+22-2=43$ dengan signifikan $=5 \%$ didapat tabel 2,016 . Karena thitung 2,680 > tabel 2,016 maka hipotesis H0 ditolak dan Ha diterima sehingga dapat dikatakan ada perbedaan hasil belajar pada kelas ekperimen dan kelas kontrol. Model Problem Based Learning efektif terhadap hasil belajar siswa pada materi pemecahan masalah matematka kelas III SD Negeri Kalicari 01 Semarang.

Dengan penelitian ini diharapkan dapat mengetahui jenis kesulitan belajar matematika yang dialami siswa, faktor yang mempengaruhi kesulitan belajar, dan mengungkapkan upaya yang dapat dilakukan untuk mengatasi kesulitan belajar matematika di kelas IV Sekolah Dasar.

\section{Metode}

Penelitian ini menggunakan jenis penelitian deskriptif kualitatif. Penelitian kualitatif adalah penelitian yang bermaksud memahami fenomena tentang apa yang dialami oleh subjek penelitian misalnya perilaku, persepsi, motivasi, tindakan, dan lain-lain, secara holistik, dan dengan cara deskripsi dalam bentuk kata-kata dan bahasa, pada suatu konteks khusus yang alamiah dengan memanfaatkan berbagai metode ilmiah (Moleong, 2012).

Penelitian ini dilaksanakan di SD Negeri Tambakrejo 03 Semarang. Penelitian ini dilakukan di kelas IV pada semester gasal tahun ajaran 2019/2020.

Teknik yang digunakan adalah menggunakan wawancara secara langsung dengan guru dan siswa kelas IV SD Negeri Tambakrejo 03 Semarang, selanjutnya melakukan observasi dan membagikan soal cerita kepada siswa. Data selanjutnya peneliti menggunakan dokumentasi untuk memperkuat data penelitian. Teknik analisis data menurut Miles dan Huberman (Sugiyono, 2015) Aktivitas dalam analisis data, yaitu : data collection, data reduction, data display, dan conclusion drawing / verification.

\section{Hasil dan Pembahasan}

Penelitian ini dilaksanakan di SD Negeri Tambakrejo 03 Semarang yang mana merupakan Sekolah Dasar Negeri yang beralamat di Jalan Tenggang, Kelurahan Tambakrejo, Kecamatan Gayamsari, Kota Semarang. Penelitian ini dilaksanakan dengan bantuan partisipasi seluruh siswa kelas IV dan guru kelas IV SD Negeri Tambakrejo 03 Semarang.

Tabel 1. Daftar Narasumber Penelitian

\begin{tabular}{|c|c|c|}
\hline Nama & Jabatan & Data yang Didapat \\
\hline Irta Rahayu, S.Pd. & Guru Kelas IV & $\begin{array}{l}\text { Pendapat mengenai faktor yang mempengaruhi } \\
\text { kesulitan belajar matematika yang dialami siswa saat } \\
\text { mengerjakan soal cerita dan upaya yang dilakukan } \\
\text { untuk mengatasi kesulitan belajar matematika } \\
\text { tersebut. }\end{array}$ \\
\hline Pratama Abi & Siswa Kelas IV & Pendapat mengenai faktor \\
\hline Alvi Aura Lestari & Siswa Kelas IV & kesulitan belajar matematika yang dialami siswa saat \\
\hline Erlangga Dwi Saputra & Siswa Kelas IV & erjakan soal cerita dan upaya yang dilakukan \\
\hline Marisa zahra Mecc & Siswa Kelas IV & litan belajar matematika. \\
\hline Marsha Du & Siswa Kelas IV & memperoleh data dari hasil pekerjaaan siswa \\
\hline M. Ridwan Anas & Siswa Kelas IV & yang menunjukkan dari 15 siswa hanya 10 siswa saja \\
\hline
\end{tabular}




\begin{tabular}{ll} 
M. Akbar Ariyanto & Siswa Kelas IV \\
Nabilah Putri Kanza & Siswa Kelas IV \\
Nurul Hidayah Oktaviani & Siswa Kelas IV \\
Ravanelli Tristan T. & Siswa Kelas IV \\
Riva Toya Aditya P. & Siswa Kelas IV \\
Wahda Zahwa Alina & Siswa Kelas IV \\
Yaka Bintang Pratama & Siswa Kelas IV \\
Widyawati Wahyuni W. & Siswa Kelas IV \\
Wildan Vega Y. & Siswa Kelas IV \\
\hline
\end{tabular}

\section{Kesulitan Belajar Matematika}

Kesulitan belajar matematika merupakan suatu kendala yang dialami siswa pada saat belajar matematika yaitu dalam menyelesaikan soal cerita materi pecahan. Hal ini sesuai dengan teori menurut Erny Untari (2014) yang menyatakan bahwa kesulitan siswa dalam menyelesaikan soal yaitu kesulitan memahami maksud soal cerita.

SD Negeri Tambakrejo 03 di kelas IV memiliki siswa sebanyak 15 siswa yang terbagi menjadi 8 siswa laki-laki dan 7 siswa perempuan, 10 siswa mengalami kesulitan belajar matematika yaitu kesulitan memahami konsep, kesulitan dalam keterampilan berhitung, dan kesulitan dalam memecahkan masalah. Dalam penelitian ini, kesulitan memahami konsep yang dialami siswa yaitu kesulitan pada konsep penjumlahan dan pengurangan pecahan dengan penyebut yang sama maupun penyebut yang berbeda. Kesulitan tersebut ditunjukkan ketika siswa tidak dapat menyelesaikan soal cerita penjumlahan dan pengurangan pecahan dengan penyebut yang sama maupun berbeda. Kurangnya pemahaman konsep menyebabkan siswa kesulitan mengerjakan soal cerita dikarenakan guru yang mengajarkan dengan cara yang kurang tepat dan tidak menggunakan contoh konkret yang dihubungkan dengan kehidupan seharihari. Kondisi tersebut seperti yang ditemukan dalam penelitian (Jamal, 2014) tentang analisis kesulitan belajar matematika dengan kesimpulan bahwa kesulitan siswa pada materi dikarenakan kurangnya pemahaman siswa dalam memahami konsep dan sering salah menggunakan rumus dalam menyelesaikan soal.

Kesulitan dalam operasi hitung dapat terjadi karena siswa melakukan kesalahan dalam mengoperasikan angka secara tidak benar. Siswa juga kesulitan dalam keterampilan menghitung karena tidak teliti ketika menghitung sesuai dengan pendapat (Runtukkahu, 2014) bahwa siswa yang mengalami kesulitan belajar matematika sering melakukan kekeliruan dalam berhitung.

Pemecahan masalah merupakan salah satu kemampuan yang harus dikuasai siswa setelah belajar matematika. Kemampuan ini sangat diperlukan siswa terkait dengan kebutuhan siswa untuk memecahkan masalah yang dihadapinya dalam kehidupan sehari-hari dan mampu mengembangkan diri mereka sendiri. Hasil analisis kesulitan memecahkan masalah pada soal cerita menunjukkan bahwa siswa tidak mampu memaknai kalimat pada soal cerita dan mengerjakan soal cerita tidak sesuai dengan langkah-langkah pemecahan masalah matematika sehingga tidak dapat menyelesaikan soal dengan benar. Hal ini sesuai dengan yang dikatakan (Jamaris, 2014) bahwa anak yang kesulitan belajar matematika mempunyai ciri pemahaman bahasa matematika yang kurang. Kurangnya pemahaman tersebut mengakibatkan siswa mengalami kesulitan dalam membuat hubungan-hubungan yang bermakna matematika, seperti yang terjadi dalam memecahkan masalah hitungan soal yang disajikan dalam bentuk cerita.

\section{Faktor yang Menyebabkan Kesulitan Belajar Matematika}

a. Faktor Internal

Faktor internal ini berasal dari diri siswa, seperti IQ siswa, sikap siswa dalam belajar, motivasi belajar, kesehatan tubuh, dan kemampuan pengindraan.

1) Tingkat IQ dari setiap siswa berbeda-beda, ada yang perkembangan kognitifnya cepat dan ada yang lambat. Berdasarkan hasil analisis dapat diketahui bahwa, di kelas IV ada siswa yang pintar dan ada pula siswa yang tidak pintar, siswa yang pintar ketika dijelaskan oleh guru akan cepat menangkap materi akan tetapi sebaliknya dengan siswa yang IQ rendah akan lambat dalam menangkap materi. Dari 15 siswa hanya 5 siswa yang mencapai kriteria ketuntasan minimal dalam pembelajaran matematika. Hal ini sesuai dengan pendapat (Slameto, 2010) mengemukakan bahwa intelegensi besar pengaruhnya terhadap kemajuan belajar seseorang, dalam keadaan yang sama siswa yang memiliki tingkat intelegensi tinggi akan lebih berhasil dalan belajar dibandingkan siswa yang memiliki tingkat intelegensi rendah.

2) Sikap Siswa dalam Belajar, sikap belajar adalah kecenderungan siswa untuk melakukan atau tidak melakukan kegiatan belajar. Sikap positif terhadap suatu mata pelajaran adalah awal yang baik untuk 
proses pembelajaran. Sebaliknya sikap negatif terhadap mata pelajaran akan berpotensi menimbulkan kesulitan belajar atau membuat hasil belajar yang kurang maksimal. Dari hasil analisis menunjukkan bahwa sikap siswa terhadap pelajaran matematika beragam, ada yang menyukai dan ada yang tidak menyukai pelajaran matematika. Siswa yang tidak menyukai pelajaran matematika mempunyai sikap negatif terhadap pembelajaran matematika sehingga siswa tidak mengikuti pembelajaran dengan baik. Hal ini sesuai dengan pendapat menurut (Abdurrahman, 2010) mengemukakan bahwa matematika merupakan bidang studi yang menurut siswa paling sulit, baik menurut siswa yang tidak mengalami kesulitan belajar dan terlebih lagi menurut siswa yang mengalami kesulitan belajar.

3) Motivasi Belajar, motivasi berfungsi mengarahkan perbuatan siswa dalam belajar. Selain motivasi oleh guru, peranan orang tua dalam pemberian dukungan untuk belajar sangatlah penting. Hasil analisis menunjukkan bahwa motivasi belajar siswa masih rendah. Siswa juga tidak mempelajari kembali materi yang telah diajarkan di sekolah ketika di rumah dan siswa tidak belajar matematika ketika tidak ada ulangan. Rendahnya motivasi siswa juga mengakibatkan siswa tidak antusias mengikuti pembelajaran matematika sehingga menimbulkan kesulitan belajar matematika. Hal ini sesuai dengan pendapat dari (Ahmadi, Abu dan Supriyono, 2013) bahwa siswa yang motivasinya lemah tampak acuh tak acuh, mudah putus asa dan perhatiannya tidak tertuju pada pelajaran akibatnya banyak mengalami kesulitan belajar.

4) Kesehatan Tubuh, kesehatan tubuh merupakan salah satu faktor yang sangat penting dalam mengikuti kegiatan belajar di sekolah. Hasil analisis menunjukkan bahwa tidak semua siswa mengalami kesulitan belajar matematika yang disebabkan masalah kesehatan. Namun ada beberapa siswa yang mengalami gangguan kesehatan seperti penyakit flu, penyakit tersebut dapat mengakibatkan siswa tidak konsentrasi dalam belajar dan mengantuk ketika pelajaran matematika sedang berlangsung, hal tersebut dapat terjadi dikarenakan kondisi fisik tidak dalam keadaan yang optimal. Keadaan tubuh yang tidak optimal mempengaruhi penerimaan siswa terhadap informasi yang disampaikan. Dan dari 15 siswa, terdapat 2 siswa yang mengalami gangguan penglihatan, dikarenakan indra penglihatan siswa mengalami rabun jauh sehingga guru menempatkan siswa di bangku paling depan untuk mempermudah siswa melihat tulisan yang ada dipapan tulis. Hal ini sesuai dengan penelitian (Guntoro, 2014) bahwa tingkat kebugaran jasmani mempengaruhi prestasi belajar siswa.

\section{b. Faktor Eksternal}

Faktor eksternal ini disebabkan oleh faktor dari luar diri siswa, meliputi variasi guru dalam mengajar, penggunaan media pembelajaran, sarana prasarana sekolah, dan lingkungan keluarga.

1) Variasi Guru dalam Mengajar

Metode yang digunakan guru dalam mengajar kurang bervariasi, guru hanya menggunakan metode konvensional. Pada awal pembelajaran guru menggunakan metode ceramah untuk membuka pelajaran, kemudian guru menjelaskan materi pecahan selanjutnya perwakilan siswa diminta maju kedepan untuk menjawab soal yang diberikan oleh guru. Dalam pembelajaran yang dilakukan, ada beberapa siswa yang merasa bosan dengan pembelajaran matematika.

Pada saat pembelajaran sedang berlangsung, guru memiliki peran yang lebih dominan. Guru sebagai center dimana semua materi penjumlahan dan pengurangan pecahan disampaikan oleh guru dan tanpa melibatkan peran siswa di dalam proses pembelajaran sehingga siswa cenderung lebih pasif karena pada saat menyampaikan materi penjumlahan dan pengurangan pecahan semua materi guru yang menyampaikan dan siswa hanya mendengarkan penjelasan guru dan mencatat apa yang dijelaskan oleh guru. Penggunaan metode yang tepat akan membuat siswa lebih mudah memahami materi dan mengurangi tingkat kebosanan siswa di dalam kelas. (Slameto, 2010) menyatakan bahwa metode mengajar yang digunakan guru kurang baik dapat berpengaruh terhadap belajar siswa.

\section{2) Penggunaan Media Pembelajaran}

Penggunaan media pembelajaran sangat membantu untuk menjelaskan materi. Media pembelajaran yang konkret penting dihadirkan dalam pembelajaran matematika. Berdasarkan hasil observasi dan wawancara dengan guru maupun siswa mengemukakan bahwa guru tidak menggunakan media pembelajaran yang konkret dalam pembelajaran matematika materi pecahan sehingga siswa belum memahami dengan baik konsep yang diajarkan yang mengakibatkan siswa kesulitan dalam memahami konsep. Guru hanya menggunakan kapur untuk menulis di papan tulis. 


\section{3) Sarana dan Prasarana di Sekolah}

Sarana dan prasarana di sekolah kurang mendukung proses pembelajaran matematika. Ruang kelas mempunyai jendela dan ventilasi sebagai keluar masuk udara sehingga ruang kelas tidak pengap akan tetapi ruang kelas tidak mempunyai kipas angin sehingga membuat siswa kurang nyaman berada di dalam kelas karena kepanasan. Selama observasi peneliti tidak menemukan ruang kelas yang menggunakan LCD yang dapat membantu guru untuk menyampaikan materi dengan lebih menarik. Kondisi lainnya yang kurang mendukung untuk pembelajaran matematika adalah tata letak lapangan yang dapat dilihat langsung dari kelas yang mengakibatkan siswa kurang berkonsentrasi ketika ada kelas lain yang sedang mengikuti pelajaran olahraga di lapangan. Situasi belajar yang kurang baik seperti itu dapat memungkinkan pelajaran terhambat (Ahmadi, Abu dan Supriyono, 2013).

\section{4) Lingkungan Keluarga}

Keluarga merupakan pusat pendidikan yang pertama bagi siswa. Bimbingan dari orang tua serta perhatian dari orang tua menjadi faktor penting dalam keberhasilan belajar siswa. Dari hasil analisis yang dilakukan diketahui siswa yang terindikasi kesulitan belajar matematika tidak selalu mendapat perhatian dari orang tua di rumah. Keadaan ekonomi keluarga menjadi salah satu penyebab orang tua kurang memberikan perhatian pada siswa. Orang tua siswa kebanyakan bekerja sebagai buruh sehingga jarang mendampingi siswa belajar dirumah, orang tua berangkat kerja di pagi hari sekalian mengantarkan anaknya ke sekolah dan pulang saat sudah petang sehingga ketika sudah di rumah orang tua sudah merasakan lelah dan mengakibatkan orang tua menjadi kurang mendukung kegiatan belajar siswa di rumah dan kegiatan belajar siswa hanya dibebankan pada pihak sekolah saja. Hal ini sesuai dengan penuturan (Ahmadi, Abu dan Supriyono, 2013) bahwa anak yang tidak mendapatkan pengawasan atau bimbingan dari orang tua kemungkinan akan banyak mengalami kesulitan belajar.

\section{Upaya Mengatasi Kesulitan Belajar Matematika}

Setelah ditemukan kesulitan yang dialami siswa dan faktor-faktor yang menyebabkan kesulitan siswa, selanjutnya akan membahas mengenai upaya mengatasi kesulitan belajar matematika. Analisis upaya mengatasi kesulitan belajar matematika kelas IV di SD Negeri Tambakrejo 03 dilakukan dengan menganalisis hasil wawancara yang dilakukan pada subjek penelitian. Dalam hal ini peneliti tidak melakukan upaya mengatasi kesulitan belajar matematika, namun peneliti menggambarkan upaya yang telah dilakukan serta memberikan saran untuk mengatasi kesulitan belajar matematika. Untuk mengetahui upaya yang dapat dilakukan untuk mengatasi kesulitan belajar dijelaskan sebagai berikut.

a. Menggunakan media pembelajaran yang konkret, penggunaan media pembelajaran yang konkret sangat penting dalam pembelajaran matematika karena siswa belum bisa berpikir dengan abstrak, siswa berpikir dengan apa yang dilihat atau benda konkret.

b. Memperbanyak latihan soal, guru perlu memberikan latihan soal yang lebih banyak kepada siswa yang kesulitan belajar matematika karena dengan semakin banyak berlatih siswa akan semakin paham. Cara memberikan latihan soal yang lebih banyak pun tidak harus dilakukan di kelas, latihan soal bisa diberikan sebagai pekerjaan rumah untuk selanjutnya dipantau perkembangan kemampuan siswa.

c. Menjalin kerjasama dengan orang tua, orang tua mempunyai peran penting dalam pemberian motivasi bagi siswa. Siswa yang diberi perhatian dengan baik di rumah akan mempunyai motivasi belajar yang baik di sekolah. Untuk itu orang tua perlu senantiasa memberikan perhatian pada perkembangan belajar matematika siswa. Contoh bentuk perhatian orang tua terhadap anaknya ialah anak didampingi ketika sedang belajar di rumah karena apabila anak sedang mengalami kesulitan dalam belajar orang tua dapat mengajari anaknya sampai anak paham dengan soal yang sedang dikerjakan, anak diberikan tambahan jam belajar di rumah berupa les.

\section{Simpulan dan Saran}

Kesulitan belajar matematika menyelesaikan soal cerita yang terjadi di kelas IV SD Negeri Tambakrejo 03 meliputi kesulitan memahami konsep, kesulitan dalam keterampilan, dan kesulitan memecahkan masalah. Kesulitan-kesulitan belajar matematika menyelesaikan soal cerita didasari dengan bukti penelitian berupa jawaban wawancara dari guru dan siswa, lembar hasil pekerjaan siswa, observasi, dan dokumentasi. Faktor yang menyebabkan kesulitan belajar matematika berasal dari faktor internal dan faktor eksternal. Faktor internal yang berasal dari siswa meliputi IQ atau intelegensi, sikap siswa dalam belajar matematika, motivasi belajar siswa yang masih rendah, kesehatan tubuh yang tidak optimal, dan kemampuan pengindraan siswa yang kurang. Sedangkan faktor eksternal yang berasal dari luar siswa antara lain kurangnya variasi mengajar guru, penggunaan media pembelajaran yang belum maksimal, 
sarana prasarana di sekolah, serta lingkungan keluarga. Upaya yang dapat dilakukan untuk mengurangi kesulitan belajar matematika berdasarkan kesulitan yang dialami dan faktor yang menyebabkan kesulitan belajar matematika antara lain menggunakan media pembelajaran yang konkret, memperbanyak latihan soal, dan menjalin kerja sama dengan orang tua siswa.

Berdasarkan penelitian diatas, maka ada beberapa saran yang bisa dipaparkan dari penelitian ini yaitu: 1) Bagi guru, Guru lebih memperhatikan kesulitan-kesulitan belajar yang dialami oleh siswa. Sebaiknya ketika guru mengajarkan matematika dengan metode pembelajaran yang bervariasi yang sesuai dengan materi yang disampaikan disertai guru dapat menggunakan media pembelajaran konkret yang tepat sesuai dengan materi. 2) Bagi siswa, Siswa hendaknya lebih memperbanyak latihan soal cerita materi pecahan agar dapat memahami soal dan mengerjakan soal sesuai dengan langkah-langkah pemecahan masalah matematika. Siswa hendaknya lebih teliti dalam mengerjakan soal, dan siswa hendaknya memiliki sikap positif pada pelajaran matematika serta lebih aktif dalam pembelajaran. 3) Bagi orang tua, Orang tua hendaknya menumbuhkan motivasi belajar siswa bahwa matematika adalah pelajaran yang menyenangkan sehingga siswa mempunyai sikap positif pada pelajaran matematika. Orang tua hendaknya lebih memperhatikan perkembangan belejar anak.

\section{Daftar Rujukan}

Abdurrahman, M. (2010). Pendidikan Bagi Anak Berkesulitan Belajar. Rineka Cipta.

Ahmadi, Abu dan Supriyono, W. (2013). Psikologi Belajar. Rineka Cipta.

Darjiani, N. N. Y., Meter, I. G., \& Negara, I. G. A. O. (2015). Analisis Kesulitan-Kesulitan Belajar Matematika Siswa Kelas V Dalam Implementasi Kurikulum 2013 di SD Piloting Se-Kabupaten Gianyar Tahun Pelajaran 2014 / 2015. E-Journal PGSD Universitas Pendidikan Ganesha, 3(1), 1-11. https://ejournal.undiksha.ac.id/index.php/JJPGSD/article/view/5070

Departemen Pendidikan Nasional. (2006). Peraturan Menteri Pendidikan Nasional Republik Indonesia No.22 tahun 2006 tentang Standar Isi. Depdiknas.

Guntoro, E. . (2014). Evaluasi kualitas nutrisi kulit dan biji buah durian fermentasi dengan Phanerochaete chrysosporium dan Neurospora crassa. Fakultas Peternakan. Universitas Andalas. Padang.

Jamal, F. (2014). Analisis Kesulitan Belajar Siswa Dalam Mata Pelajaran Matematika Pada Materi Peluang Kelas XI IPA SMA Muhammadiyah Meulaboh Johan Pahlawan. Jurnal MAJU Uurnal Pendidikan Matematika), 1(1), 18-36. http://www.ejournal.stkipbbm.ac.id/index.php/mtk/article/view/232

Jamaris, M. (2014). Kesulitan Belajar: Perspektif, Asesmen, dan Penanggulangannya Bagi Anak Usia Dini dan Usia Sekolah. Ghalia Indah.

Moleong, L. (2012). Metodologi Penelitian Kualitatif. PT Remaja Rosdakarya.

Nugroho, R. A. (2017). Analisis Kesulitan Siswa dalam Menyelesaikan Soal Cerita pada Materi Pecahan Ditinjau dari Pemecahan Masalah Polya.

Rifaldiyah, M. Y. S. W. Y. (2019). Penerapan Model Problem Based Learning terhadap Hasil Belajar Kognitif Pemecahan Masalah Matematika. TSCJ, 2(1), 19-26.

Roebyanto, G. \& S. H. (2017). Pemecahan Masalah Matematika Untuk PGSD. PT Remaja Rosdakarya.

Runtukkahu, J. T. (2014). Pembelajaran Matematika Dasar bagi Anak Berkesulitan Belajar. Pustaka Pelajar.

Slameto. (2010). Belajar dan Faktor-Faktor yang Mempengaruhinya. Rineka Cipta.

Sugiyono. (2015). Metode Penelitian Pendidikan (Pendekatan Kuantitatif, Kualitatif, dan R\&D). Alfabeta.

Syafiudin, M. A., Hartoyo, A., \& Nursangaji, A. (2014). Kesulitan siswa menyelesaikan soal mengenai jarak dalam bangun ruang berdasarkan model kesulitan newman. 